\title{
Pengaruh Financial Distress dan Good Corporate Governance pada Praktik Tax Avoidance
}

\author{
I Gede Ambara Cita ${ }^{1}$ \\ Fakultas Ekonomi dan Bisnis \\ Universitas Udayana, Indonesia. \\ Email: ambaracita22@gmail.com
}

\author{
Ni Luh Supadmi \\ Fakultas Ekonomi dan Bisnis \\ Universitas Udayana, Indonesia.
}

\begin{abstract}
ABSTRAK
Usaha meminimalisir pembayaran pajak dari nominal seharusnya secara legal disebut tax avoidance.Penelitian ini bertujuan untuk menguji pengaruh financial distress dan good corporate governance pada tax avoidance yang diproksikan dengan cash effective tax rate (CETR). Penelitian ini dilakukan di perusahaan sektor consumer goods yang terdaftar di Bursa Efek Indonesia tahun 2013-2017. Penentuan jumlah sampel menggunakan metode purposive sampling dan didapatkan sampel sebanyak 105 sampel.Data dianalisis menggunakan analisis regresi linier berganda. Berdasarkan hasil analisis ditemukan financial distress berpengaruh negatif pada tax avoidance, kepemilikan institusional berpengaruh positif pada tax avoidance, komisaris independen berpengaruh positif pada tax avoidance, dan komite audit berpengaruh positif pada tax avoidance.
\end{abstract}

Kata Kunci : Financial Distress; Kepemilikan Institusional; Komisaris Independen; Komite Audit; Tax Avoidance.

\section{The Effect of Financial Distress and Good Corporate Governance on Tax Avoidance Practices}

\section{ABSTRACT}

Efforts to minimize tax payments from nominal should be legally called tax avoidance. This study aims to examine the effect of financial distress and good corporate governance on tax avoidance that is proxied by the cash effective tax rate (CETR). This research was conducted in the consumer goods sector companies listed on the Indonesia Stock Exchange in 2013-2017. Determination of the number of samples using purposive sampling method and obtained a sample of 105 samples. Data were analyzed using multiple linear regression analysis. Based on the results of the analysis found financial distress has a negative effect on tax avoidance, institutional ownership has a positive effect on tax avoidance, independent commissioners have a positive effect on tax avoidance, and audit committees have a positive effect on tax avoidance.

$\begin{array}{ll}\text { Keywords: } & \text { Financial Distress; Institutional Ownership; } \\ & \text { Independent Commissioner; Audit Committee; Tax } \\ & \text { Avoidance. }\end{array}$

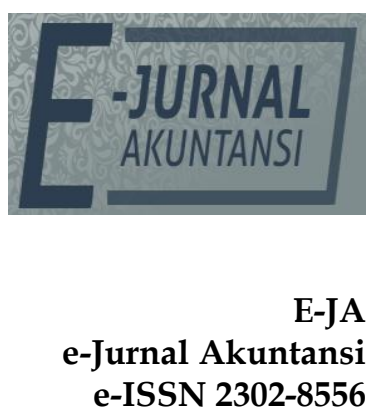

Vol. 29 No. 3

Denpasar, Desember

2019

Hal. 912-927

Artikel masuk:

25 Juni 2019

Tanggal diterima:

07 Juli 2019 


\section{PENDAHULUAN}

Sumber penerimaan negara yang terbesar salah satunya adalah penerimaan pajak.Besar-kecilnya penerimaan negara dari pajak salah satunya dipengaruhi oleh tingkat kepatuhan wajib pajak. Bagi perusahaan pajak menjadi perhatian yang cukup signifikan, karena bagi perusahaan pajak dapat mengurangi jumlah laba bersih yang akan diterima perusahaan, sehingga perusahaan menekan pembayaran pajak serendah mungkin. Berbagai upaya dapat dilakukan oleh perusahaan dalam menekan jumlah beban pajak yang harus dibayar.

Sistem pemungutan pajak di Indonesia menganut sistem self-assessment, yaitu suatu sistem pengenaan pajak yang memberi wewenang kepada wajib pajak untuk menghitung, memperhitungkan, menyetor dan melaporkan sendiri besarnya pajak yang terutang. Self assessment system yaitu wajib pajak memiliki kewajiban untuk menghitung kewajiban pajak yang dimiliki dan memiliki pengetahuan mengenai pembayaran dan sebagainya hingga terpenuhi.

Persepsi masyarakat mengenai pajak masih banyak yang negatif. Masyarakat masih menganggap pajak sebagai pengurang dari penghasilan mereka dan bukan kewajiban yang harus dibayarkan.Persepsi negatif tersebut membuat masyarakat mengelola ulang pajaknya agar pajak yang dibayarkan tidak banyak.Upaya untuk menekan jumlah pajak yang harus dibayarkan secara legal disebut dengan penghindaran pajak atau tax avoidance, sedangkan upaya untuk menekan jumlah pajak yang harus dibayarkan secara ilegal disebut dengan tax evasion (Maraya dan Yendrawati, 2016). Tax avoidance merupakan cara untuk menekan jumlah pajak yang harus dibayarkan yang sering digunakan. Tax avoidance merupakan metode yang legal dan sering digunakan. Penggunaan metode ini dengan memanfaatkan celah yang terdapat pada aturan-aturan perpajakan (Santoso, 2014).

Meskipun legal, pemerintah mengharapkan agar perusahaan tidak melakukan tindakan tax avoidance. Tax avoidance bukanlah hal baru yang terjadi di Indonesia. Realisasi pemungutan pajak di Indonesia tidak sesuai dengan yang ditargetkan, tahun 2017 efektivitas pemungutan pajak hanya mencapai 89,4 persen. Wajib pajak berusaha seminimal mungkin memenuhi kewajiban pajak yang harus dibayarkan dengan melakukan praktik penghindaran pajak (Arianandini dan Ramantha, 2018). Target dan realisasi penerimaan pajak dari tahun 2013 dan 2017 disajikan pada Tabel 1 berikut.

Tabel 1. Target dan Realisasi Penerimaan Pajak Tahun 2013-2017

\begin{tabular}{cccc}
\hline Tahun & $\begin{array}{c}\text { Target Penerimaan } \\
\text { Pajak } \\
\text { (Dalam Triliun } \\
\text { Rupiah) }\end{array}$ & $\begin{array}{l}\text { Realisasi } \\
\text { Pajak } \\
\text { (Dalam Triliun Rupiah) }\end{array}$ & $\begin{array}{l}\text { Penerimaan } \\
(\%)\end{array}$ \\
\hline 2013 & $1.148,0$ & $1.077,3$ & $\begin{array}{l}\text { Efektivitas } \\
\text { Pemungutan Pajak } \\
2014\end{array}$ \\
2015 & $1.246,0$ & $1.143,0$ & 93,8 \\
2016 & $1.489,3$ & $1.240,4$ & 83,3 \\
2017 & $1.539,2$ & $1.285,0$ & 83,5 \\
\hline
\end{tabular}

Sumber: www.kemenkeu.go.id 
Pada tahun 2016 pemerintah menerapkan kebijakan Tax Amnesty yang dapat meningkatkan jumlah realisasi pemungutan pajak setelah mengalami penurunan selama tahun 2013 sampai 2015. Tahun 2016 terlihat peningkatan realisasi penerimaan pajak dari tahun sebelumnya namun belum memenuhi target. Seharusnya target tersebut dapat terealisasi dengan adanya kebijakan Tax Amnesty. Hal tersebut mengindikasikan bahwa masih terdapat tindakan penghindaran pajak yang menyebabkan tidak tercapainya target penerimaan pajak yang ditetapkan oleh pemerintah.

Terdapat beberapa faktor yang mempengaruhi manajemen untuk melakukan tax avoidance. Maharani dan Suardana (2014) dan Dewi dan Sari(2015) menyebutkan salah satu faktornya adalah Financial Distress. Indikasi awal akan terjadinya kebangkutan dengan gejala kesulitan keuangan atau likuiditas disebut dengan Financial Distress. Shleifer dan Vishny (1997) dalam penelitiannya mendapat temuan mengenai adanya hubungan yang positif antara financial distress pada tax avoidance.

Perekonomian di dunia akan selalu mengalami keadaaan pasang dan surut. Kondisi pelaku perekonomian juga tidak akan selamanya baik. Ketika krisis melanda banyak perusahaan yang mengalami kesulitan keuangan atau yang disebut dengan financial distress. Ketika perusahaan merasa bahwa tingkat kesulitan keuangan yang dialami semakin tinggi sehingga kemungkinan perusahaan tersebut bangkrut lebih tinggi maka praktik tax avoidance sangat mungkin dilakukan (Brondolo, 2015). Hasil penelitian dari Meilia dan Adnan(2017)dalam penelitiannya yang mengangkat topik yang sama yaitu mengenai tax avoidance menemukan kesimpulan bahwa ketika financial distress suatu perusahaan meningkat, manajemen perusahaan tersebut cenderung melakukan tax avoidance.

Baik buruknya penerapan CG oleh perusahaan akan berdampak pada kelangsungan kinerja keuangan perusahaan tersebut. Ketika corporate governancetidak diterapkan dengan baik maka akan berdampak pada turunnya kinerja keuangan perusahaan dan dalam jangka panjang akan berakhir pada financial distress (Radifan, 2015). Corporate governance dapat dilakukan secara internal ataupun eksternal (Fadhilah 2014). Corporate governance secara internal yaitu melakukan pengendalian melalui struktur organisasi dan proses internal. Corporate governance secara eksternal yaitu melakukan pengendalian melalui pasar atau pemegang saham.

Kepemilikan institusional adalah proporsi kepemilikan saham yang dimiliki oleh pemilik institusi dan blockholder pada akhir tahun (Wahyudi, 2014). Dewan komisaris melakukan pembentukan sebuah komite yang memiliki tanggung jawab terhadap dewan komisaris dan komite ini disebut dengan komite audit. Tanggung jawab yang dipegang oleh komite audit adalah membantu dewan komisaris dalam melakukan tugasnya mengawasi perusahaan. Pengawasan yang dilakukan oleh komite audit dapat meminimalisir perilaku menyimpang yang mungkin dilakukan oleh manajemen. Manajemen perusahaan menyusun laporan keuangan dibawah pengawasan komite audit.

Terdapat perbedaan hasil dari penelitian sebelumnya yaitu pada penelitian yang dilakukan oleh (Reza, 2012), ditemukan adanya hubungan yang negatif antara besarnya persentase anggota dewan komisaris pada tax avoidance. 
Timothy (2010) dalam penelitiannya justru menemukan hubungan positif antara persentase anggota dewan komisaris pada tax avoidance.

Dengan memiliki harga saham yang rata-rata tinggi, sektor Consumer Goodsdipilih sebagai objek yang akan diteliti. Rata-rata harga saham yang tinggi ini memiliki pengaruh yang besar pada penilaian kemajuan perusahaan manufaktur. Harga saham di berbagai sektor yang tercatat di Bursa Efek Indonesia selama tahun 2015-2017 disajikan pada Tabel 2 berikut

Tabel 2. Harga Saham di Berbagai Sektor yang Tercatat di Bursa Efek Indonesia selama Tahun 2015-2017

\begin{tabular}{|c|c|c|c|c|}
\hline \multirow{2}{*}{ Sector } & \multicolumn{4}{|c|}{ Harga Saham (Rp) } \\
\hline & 2015 & 2016 & 2017 & Rata-Rata \\
\hline Agriculture & 1719,262 & 1864,249 & 1616,307 & 1733,273 \\
\hline Mining & 811,072 & 1384,706 & 1593,999 & 1263,259 \\
\hline Basic Industry dan Chemicals & 407,839 & 538,189 & 689,219 & 545,082 \\
\hline Miscellaneous Industry & 1057,275 & 1370,628 & 1381,177 & 1269,693 \\
\hline Consumer Goods Industry & 2064,91 & 2324,281 & 2861,391 & 2416,861 \\
\hline $\begin{array}{l}\text { Property, Realestate dan Building } \\
\text { Construction }\end{array}$ & 490,933 & 517,81 & 495,51 & 501,418 \\
\hline $\begin{array}{l}\text { Infrastructure, Utilities and } \\
\text { Transportation }\end{array}$ & 981,333 & 1055,587 & 1183,708 & 1073,543 \\
\hline Finance & 687,039 & 811,893 & 1140,837 & 879,923 \\
\hline Trade dan Service & 849,527 & 860,654 & 921,589 & 877,257 \\
\hline
\end{tabular}

Sumber: www.idx.co.id, 2018

Tabel 2 menunjukan bahwa sektor yang memiliki rata-rata harga saham tertinggi yaitu sektor Consumer Goods, dari tahun 2015 hingga 2017 rata-rata harga saham pertahun di perusahaan sektor Consumer Goods terus mengalami peningkatan. Peneliti termotivasi untuk meneliti sektor Consumer Goods karena ingin mengetahui apakah sektor Consumer Goods yang merupakan sektor dengan rata-rata saham tertinggi, melakukan penghindaran pajak.

Teori agensi dan teori legitimasi merupakan teori dasar yang digunakan dalam memahami isu tentang pengaruh financial distress dan corporate governance pada praktik tax avoidance. Jensen dan Meckling (1976) mengungkapkan pengertian dari teori agensi yaitu hubungan kontrak kerja sama antaragent dan principal. Dalam kontrak kerja ini agent diberikan wewenang oleh principal untuk menjalankan aktivitas perusahaan sesuai visi misi dan tujuan yang telah ditetapkan oleh principal. Yang dimaksud dengan principal adalah pemberi wewenang yaitu pemegang saham, pemilik atau investor yang menginvestasikan dananya pada perusahaan. Yang dimaksud dengan agent disini adalah orang yang diberikan wewenang oleh principal yaitu manajer perusahaan.

Legitimasi adalah melakukan penyamaan persepsi atau pengertian akan suatu hal yang kemudian disesuaikan dengan aturan atau norma yang berlaku (Suchman, 1995). Suchman (1995) memiliki pendapat mengenai legitimasi yaitu hubungan antara perusahaan dengan masyarakat dimana masyarakat memberikan sesuatu yang dicari atau diinginkan oleh perusahaan kepada perusahaan.Sistem perusahaan dengan legitimasi berarti perusahaan mengatur sistem dalam perusahaannya dengan orientasi bahwa perusahaan tersebut berpihak kepada masyarakat (Gray et al, 1996). 
Masri dan Martani (2012) di dukung oleh penelitian dari Rani (2017) menyatakan pengaruh negatif financial distress terhadap tax avoidance. Perusahaan yang melakukan upaya tax avoidance ketika perusahaan tersebut berada pada posisi financial distress hal tersebut akan menyebabkan penurunan pada citra perusahaan. perusahaan yang merugi akan terbebas dari beban pajak penghasilan dan mendapatkan fasilitas kompensasi kerugian pada masa mendatang.Hipotesis yang dibangun adalah:

$\mathrm{H}_{1}$ : Financial distress berpengaruh negatif terhadap praktik Tax Avoidance.

Fadhilah (2014) menyatakan pengaruh negatif kepemilikan institusional terhadap tax avoidance. Dalam teori agensi disebutkan hubungan antara pemilik saham dan manajamen, semakin tinggi saham yang dimiliki oleh pihak institusional secara otomatis akan membuat pengawasan yang tinggi terhadap perilaku manajemen di dalam perusahaan sehingga masalah keagenan menjadi berkurang dan meminimalisir peluang terjadinya tax avoidance.Hipotesis yang dibangun adalah:

$\mathrm{H}_{2}$ : Kepemilikan Institusional berpengaruh negatif terhadap tax avoidance.

Prakosa (2014) menemukan bahwa ukuran dewan komisaris independen memiliki pengaruh negatif terhadap tax avoidance. Dalam teori agensi disebutkan bahwa, untuk mengurangi kesimpangan informasi maka dibentuk dewan komisaris yang merupakan tangan kanan dari pemilik saham. Dewan komisaris independen bertugas untuk menjaga manajemen agar menjalankan kegiatannya tidak bertentangan dengan hukum maupun aturan-aturan yang telah di tetapkan. Hipotesis yang dibangun adalah:

$\mathrm{H}_{3}$ : Ukuran Dewan Komisaris berpengaruh negatif terhadap Tax Avoidance.

Maharani dan Suardana (2014) menyebutkan bahwa komite audit memiliki pengaruh negatif terhadap tax avoidance, ini di dukung oleh penelitian dari Annisa dan Kurniasih (2012), yang menyatakan bahwa komite audit dapat memperkuat pengawasan pengawasan terhadap tindakan pengukuran dan pengungkapan akuntansi yang tidak tepat sehingga akan mengurangi tindakan kecurangan oleh manajemen pajak. Dalam pengawasannya, semakin besar porsi komite audit dalam perusahaan, maka pengawasan akan pembuatan laporan keuangan perusahaan akan semakin besar dan kegiatan perusahaan terhadap tax avoidance semakin kecil. Hipotesis yang dibangun adalah:

$\mathrm{H}_{4}$ : Komite Audit berpengaruh negatif terhadap Tax Avoidance.

\section{METODE PENELITIAN}

Lokasi dari penelitian ini dilakukan pada BEI dengan meneliti perusahaan Consumer Goods yang terdaftar di BEI dengan mengakses laman www.idx.co.id dan www.idnfinancials.com untuk mendapatkan informasi yang diperlukan tentang perusahaan Consumer Goods serta untuk memperoleh laporan keuangan tahunan perusahaan.

Objek pada penelitian ini adalah tax avoidance, financial distress, kepemilikan institusional,ukuran dewan komisaris independen, dan komite audit pada perusahaan sektor consumer goods yang terdaftar di Bursa Efek Indonesia dari tahun 2013 sampai 2017.Variabel terikat yang dipilih adalah tax avoidance. Variabel bebas yang dipilih adalah adalah financial distress, 
kepemilikan institusional, ukuran dewan komisaris independen, dan komite audit.

Upaya untuk menekan jumlah pajak yang harus dibayarkan secara legal disebut dengan penghindaran pajak atau tax avoidance, sedangkan upaya untuk menekan jumlah pajak yang harus dibayarkan secara ilegal disebut dengan tax evasion (Maraya dan Yendrawati, 2016). Tax avoidance merupakan cara untuk menekan jumlah pajak yang harus dibayarkan yang sering digunakan. Tax avoidance merupakan metode yang legal dan sering digunakan. Penggunaan metode ini dengan memanfaatkan celah yang terdapat pada aturan-aturan perpajakan (Santoso, 2014).

Tax avoidance merupakan cara untuk menekan jumlah pajak yang harus dibayarkan namun tidak melanggar peraturan perpajakan dengan menuruti peraturan yang ada. Pengukuran tax avoidance dalam penelitian ini dihitung melalui cash effective tax rates (CETR). Penggunaan CETR juga dilakukan oleh beberapa peneliti seperti Chen et al.(2010) dan Minnick dan Noga(2010). CETR dalam penelitian ini akan dihitung dengan rumus yang diperagakan oleh Hanlon dan Heitzman (2010), yaitu:

CETR $=\frac{\text { Cash } \text { Tax Paid } i, t}{\text { Pretax Income } i, t}$

Terdapat beberapa faktor yang mempengaruhi manajemen untuk melakukan tax avoidance. Maharani dan Suardana (2014) dan Dewi dan Sari (2015) menyebutkan salah satu faktornya adalah Financial Distress. Indikasi awal akan terjadinya kebangkutan dengan gejala kesulitan keuangan atau likuiditas disebut dengan Financial Distress. Lanis dan Richardson (2013) dalam penelitiannya mendapat temuan mengenai adanya hubungan yang positif antara financial distress pada tax avoidance. Perekonomian di dunia akan selalu mengalami keadaaan pasang dan surut. Kondisi pelaku perekonomian juga tidak akan selamanya baik. Ketika krisis melanda banyak perusahaan yang mengalami kesulitan keuangan atau yang disebut dengan financial distress.

Kondisi ketika arus kas operasi perusahaan tidak mencukupi untuk memenuhi kewajiban lancar (seperti kredit perdagangan atau beban bunga) disebut dengan Financial distress. Financial distress sendiri diukur dengan menggunakan Altman Z-Score (Altman \& Hotchkiss, 2011), yaitu:

$Z=1.2 A+1.4 B+3.3 C+0.6 D+1 E$

Keterangan:

$\mathrm{A}=$ Aset lancar-utang lancar / total aset

$\mathrm{B}=$ Laba ditahan $/$ Total aset

$\mathrm{C}=$ Laba sebelum pajak / Total aset

$\mathrm{D}=$ Jumlah lembar saham $\times$ Harga per lembar saham / total utang

$\mathrm{E}=$ Penjualan $/$ Total aset

Kepemilikan institusional adalah proporsi kepemilikan saham yang dimiliki oleh pemilik institusi dan blockholder pada akhir tahun (Wahyudi, 2014). Kepemilikan institusional merupakan institusi pendiri perusahaan yang memiliki proporsi kepemilikan dari perusahaan yang didirikan. Perhitungan kepemilikan institusional ini mengacu pada penelitian Carlson dan Bathala (1997) serta Khurana dan Moser (2009) dengan rumus sebagai berikut:

Kepemilikan Institusional $=\frac{\text { Kepemilikan saham institusional }}{\text { Jumlah saham yang beredar }}$ 
Dewan komisaris independen merupakan pihak yang tidak terafiliasi dengan pemegang saham pengendali, anggota direksi dan dewan komisaris lain. Perhitungan komisaris independen ini mengacu pada penelitian Annisa dan Kurniasih (2012) dengan menggunakan rumus sebagai berikut.

Proporsi komisaris independen $=\frac{\sum \text { Komisaris Independen }}{\sum \text { Anggota Dewan Komisaris }}$

Komite audit merupakan komite yang dibentuk oleh dewan komisaris dan bertanggung jawab kepada dewan komisaris dalam membantu melaksanakan pengawasan dalam menyusun laporan keuangan. Dewan komisaris melakukan pembentukan sebuah komite yang memiliki tanggung jawab terhadap dewan komisaris dan komite ini disebut dengan komite audit. Tanggung jawab yang dipegang oleh komite audit adalah membantu dewan komisaris dalam melakukan tugasnya mengawasi perusahaan. Pengawasan yang dilakukan oleh komite audit dapat meminimalisir perilaku menyimpang yang mungkin dilakukan oleh manajemen. Manajemen perusahaan menyusun laporan keuangan dibawah pengawasan komite audit.

Dalam penelitian ini yang menjadi populasi adalah seluruh perusahaan Consumer Goods yang terdaftar di BEI pada periode 2013-2017. Jumlah perusahaan Consumer Goods yang terdaftar di Bursa Efek Indonesia berjumlah 49 perusahaan.Metode purposive samplingdigunakan sebagai teknik pengambilan sampel. Kriteria yang digunakan dalam pengambilan sampel untuk penelitian ini adalah sebagai berikut: Perusahaan Consumer Goods yang terdaftar di Bursa Efek Indonesia selama 5 tahun periode pengamatan yaitu 2013-2017.Perusahaan yang mempublikasikan laporan keuangan pada tahun 2013-2017 secara lengkap.Perusahaan Consumer Goods yang memiliki laba setelah pajak bernilai positif untuk tahun 2013-2017. Perusahaan yang mengalami kerugian tidak memiliki kewajiban untuk membayar pajak, sehingga akan menghasilkan tarif pajak efektif terdistorsi (Richardson et al, 2015). Perusahaan Consumer Goods dengan nilai CETR kurang dari satu agar tidak menimbulkan masalah dalam estimasi model (Gupta dan Newberry, 1997)

Data kuantitatif yang digunakan berasal dari laporan keuangan perusahaan manufaktur yang terdaftar di BEI tahun 2013-2017. Data kualitatif yang digunakan berasal dari penelitian terdahulu yang dapat mendukung hasil analisis. Data sekunder berasal dari web, majalah, buku, dan jurnal penelitian terdahulu. Data sekunder dalam penelitian ini diperoleh peneliti melalui web resmi www.idx.co.id. Teknik analisis data yang digunakan adalah regresi linier berganda menggunakan rumus sebagai berikut.

$Y=\alpha+\beta_{1} X_{1}+\beta_{2} X_{2}+\beta_{3} X_{3}+\beta_{4} X_{4}+e$

Keterangan:

$\mathrm{Y} \quad=$ Tax Avoidance

a $\quad=$ Konstanta

$\beta 1-\beta 4=$ Koefisien regresi variabel $X_{1}, X_{2}, X_{3}$, dan $X_{4}$

$\mathrm{X}_{1} \quad=$ Financial Distress

$\mathrm{X}_{2} \quad=$ Kepemilikan Manajerial

$\mathrm{X}_{3} \quad=$ Ukuran Dewan Komisaris

$\mathrm{X}_{4} \quad=$ Komite Audit

$\mathrm{e}=$ Error 


\section{HASIL DAN PEMBAHASAN}

Deskripsi variabel dalam penelitian dilakukan pada variabel financial distress, kepemilikan institusional, komisaris independen, komite audit dan tax avoidance. Hasil uji statistik deskriptif penelitian ini disajikan pada tabel 3 berikut.

\section{Tabel 3. Hasil Uji Statistik Deskriptif}

\begin{tabular}{llllll}
\hline Descriptive Statistics & & & & & \\
\hline & $\mathrm{N}$ & Minimum & Maximum & Mean & Std. Deviation \\
Tax Avoidance & 105 & 0,0832 & 0,7238 & 0,292917 & 0,1188735 \\
Financial Distress & 105 & 1,0510 & 5,6813 & 3,050382 & 1,0061156 \\
Kepemilikan & & & & & \\
Institusional & 105 & 0,0514 & 0,9818 & 0,713101 & 0,1992571 \\
Komisaris Independen & 105 & 0,2000 & 0,8000 & 0,419448 & 0,1241480 \\
Komite Audit & 105 & 3,0000 & 4,0000 & 3,085714 & 0,2812843 \\
Valid N (listwise) & 105 & & & & \\
\hline
\end{tabular}

Sumber: Data Penelitian, 2019

Tax avoidance pada penelitian ini diproksikan dengan cash effective tax rates (CETR). Berdasarkan hasil uji statistik deskriptif, diperoleh nilai minimum CETR sebesar 0,0832 dan nilai maksimum sebesar 0,7238. Variabel tax avoidance memiliki nilai rata-rata sebesar 0,292917. Hal ini menunjukan bahwa nilai ratarata kas pajak dalam suatu perusahaan pajak sebesar 29,1917 persen dari laba sebelum pajaknya. Standar deviasi tax avoidance sebesar 0,1188735 nilai ini lebih rendah dibandingkan dengan nilai rata-rata, hal ini menunjukan bahwa sebaran data tax avoidance sudah merata.

Pengukuran financial Distress dilakukan dengan menggunakan proksi Altman Z-Score. Variabel Financial Distress memiliki nilai minimum sebesar 1,0510 dan memiliki nilai maksimum sebesar 5,6813. Variabel financial distress memiliki nilai rata-rata sebesar 3,0503. Nilai standar deviasi financial distress sebesar 1,00611 hal ini menunjukan bahwa terjadi perbedaan nilai financial distress yang diteliti terhadap nilai rata-ratanya sebesar 100,6\%.

Pengukuran kepemilikan institusional dalam penelitian ini diukur dengan besarnya presentase kepemilikan saham intitusional. Variabel kepemilikan institusional memiliki nilai minimum sebesar 0,0514 dan nilai maksimum sebesar 0,9818. Variabel kepemilikan institusional memiliki nilai ratarata sebesar 0,7131. Standar deviasi sebesar 0,19925 nilai ini lebih rendah dibandingkan dengan nilai rata-rata, hal ini menunjukan bahwa sebaran data kepemilikan institusional sudah merata.

Komisaris independen dalam penelitian ini dihitung dengan membandingkan jumlah komisaris independen dengan total jumlah komisaris. Variabel komisaris independen memiliki nilai minimum sebesar 0,2000 dan memiliki nilai maksimum sebesar 0,800. Variabel komisaris independen memiliki nilai rata-rata sebesar 0,4194. Standar deviasi sebesar 0,12414 nilai ini lebih rendah dibandingkan dengan nilai rata-rata, hal ini menunjukan bahwa sebaran data komisaris independen sudah merata.

Komite audit dalam penelitian ini dihitung dari jumlah komite audit yang berada di perusahaan. Variabel komite audit memiliki nilai minimum 3,0000 dan nilai maksimum sebesar 4,0000. Variabel komite audit memiliki nilai rata-rata sebesar 3,0857. Standar deviasi sebesar 0,28128 nilai ini lebih rendah 
dibandingkan dengan nilai rata-rata, hal ini menunjukan bahwa sebaran data komite audit sudah merata.

Hasil uji normalitas dalam penelitian ini disajikan pada tabel 4 berikut.

Tabel 4. Uji Normalitas One-Sample Kolmogorov-Smirnov Test

Unstandardized Residual

\begin{tabular}{llc}
\hline$N$ & & 105 \\
Normal Parameters ${ }^{a, b}$ & Mean & 0,000 \\
& Std. Deviation & 0,8344 \\
Most Extreme Differences & Absolute & 0,073 \\
& Positive & 0,073 \\
& Negative & $-0,053$ \\
Test Statistic & & 0,752 \\
Asymp. Sig. (2-tailed) & & 0,623 \\
\hline
\end{tabular}

Sumber: Data Penelitian, 2019

Tabel 4 menunjukan bahwa hasil uji Kolmogorov-Smirnov sebesar 0,752 dengan niai signifikansi sebesar 0,623. Hal ini dapat disimpulkan bahwa kelima variabel berdistribusi normal sehingga asumsi normalitas telah terpenuhi. berikut.

Hasil uji multikolinearitas dalam penelitian ini disajikan pada tabel 5

Tabel 5. Uji Multikolinearitas

Coefficients $^{a}$

Collinearity Statistics

\begin{tabular}{llcc} 
Model & & Tolerance & VIF \\
\hline 1 & Financial Distress $\left(X_{1}\right)$ & 0,492 & 2,034 \\
& Kepemilikan Institusional $\left(X_{2}\right)$ & 0,408 & 2,449 \\
& Komisaris Independen $\left(X_{3}\right)$ & 0,731 & 1,367 \\
& Komite Audit $\left(X_{4}\right)$ & 0,923 & 1,083 \\
\hline
\end{tabular}

Sumber: Data Penelitian, 2019

Berdasarkan Tabel 5 diperoleh nilai tolerance dan VIF dari seluruh variabel tersebut menunjukkan bahwa nilai tolerance untuk setiap variabel lebih besar dari $10 \%$ dan nilai VIF lebih kecil dari 10 yang berarti model persamaan regresi bebas dari multikolinearitas.

Hasil uji heteroskedastisitas dalam penelitian ini disajikan pada tabel 6 berikut.

\section{Tabel 6. Hasil Uji Heteroskedastisitas}

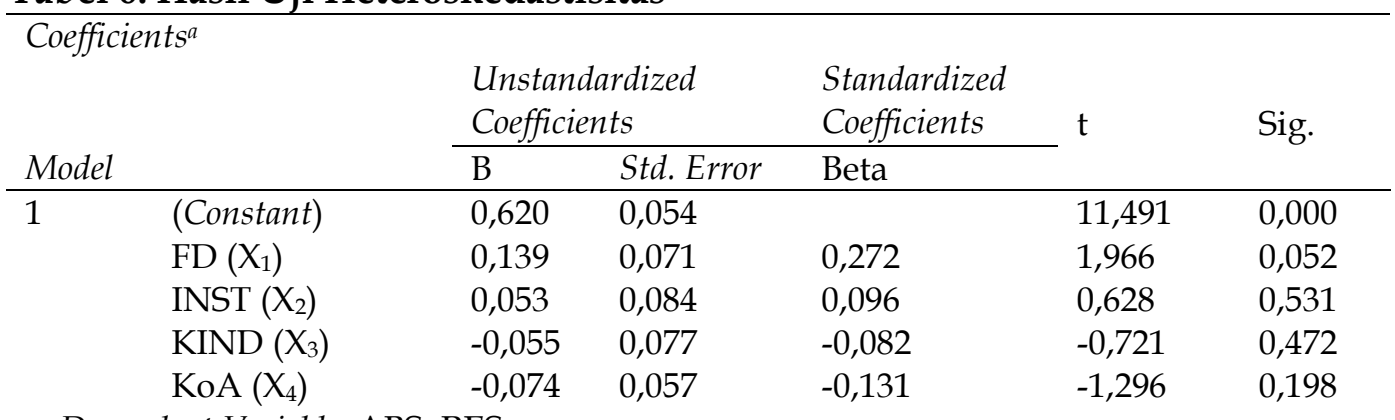

a. Dependent Variable: ABS_RES

Sumber: Data Penelitian, 2019 
Pada Tabel 6 dapat dilihat bahwa nilai signifikansi dari variabel Financial Distress sebesar 0,052, Kepemilikan institusional sebesar 0,531, nilai signifikansi variabel Komisaris independen sebesar 0,472, dan nilai signifikansi variabel komite audit sebesar 0,198. Nilai dari keempat variabel yang diujikan terbebas dari gejala heteroskedastisitas karena nilai yang dihasilkan telah melebihi 0,05.

Hasil uji autokorelasi dalam penelitian ini disajikan pada tabel 7 berikut.

\section{Tabel 7. Hasil Uji Autokorelasi}

Model Summary ${ }^{\mathrm{b}}$

Adjusted $R$ Std. Error of the

\begin{tabular}{llllll} 
Model & $\mathrm{R}$ & $R$ Square & Square & Estimate & Durbin-Watson \\
\hline 1 & $0,479^{\mathrm{a}}$ & 0,230 & 0,199 & 0,85095840 & 1,785
\end{tabular}

a. Predictors: (Constant), KoA, KIND, INST, FD

b. Dependent Variable: CETR

Sumber: Data Penelitian, 2019

Berdasarkan Tabel 7 didapat nilai Durbin Watson sebesar 1,785, sehingga dapat disimpulkan nilai DW 1,7617 <1,785 $\leq 2,2383$ yang diperoleh dalam model regresi ini bahwa tidak ada autokorelasi positif atau negatif.

Hasil uji regresi linier berganda dalam penelitian ini disajikan pada tabel 8 berikut.

Tabel 8. Hasil Uji Regresi Linier Berganda

Coefficients $^{a}$

$\begin{array}{ll}\text { Unstandardized } & \text { Standardized } \\ \text { Coefficients } & \text { Coefficients }\end{array}$

\begin{tabular}{lllllll} 
Model & & $\mathrm{B}$ & Std. Error & Beta & $\mathrm{t}$ & Sig. \\
\hline 1 & (Constant) & $-0,163$ & 0,086 & & $-1,888$ & 0,062 \\
& FD $\left(\mathrm{X}_{1}\right)$ & $-0,353$ & 0,113 & $-0,390$ & $-3,115$ & 0,002 \\
& INST $\left(\mathrm{X}_{2}\right)$ & $-0,284$ & 0,134 & $-0,291$ & $-2,120$ & 0,036 \\
& KIND $\left(\mathrm{X}_{3}\right)$ & $-0,461$ & 0,123 & $-0,386$ & $-3,765$ & 0,000 \\
& KoA $\left(\mathrm{X}_{4}\right)$ & $-0,207$ & 0,092 & $-0,206$ & $-2,260$ & 0,026
\end{tabular}

a. Dependent Variable: Tax Avoidance

Sumber: Data Penelitian, 2019

Tabel 8 persamaan regresi yang digunakan dalam penelitian ini dapat ditulis sebagai berikut:

$$
\mathrm{Y}=-0,0163-0,353 \mathrm{X} 1-0,284 \mathrm{X} 2-0,461 \mathrm{X3}-0,207 \mathrm{X} 4+\mathrm{e}
$$

a menyatakan bahwa jika variabel financial distress, kepemilikan institusional, komisaris independen, dan komite audit sama dengan nol, maka menunjukan nilai tax avoidance akan berkurang.

Nilai koefisien $\beta_{1}$ sebesar -0,353 menunjukan jika nilai financial distress $\left(X_{1}\right)$ meningkat sebesar 1 satuan, maka CETR menurun sebesar 0,353 satuan dengan asumsi variabel independen lainnya konstan. Semakin rendah nilai CETR mencerminkan semakin tingginya tingkat tax avoidance dan sebaliknya, sehingga penurunan nilai CETR perusahaan perusahaan menunjukan peningkatan tindakan tax avoidance $(\mathrm{Y})$ yang dilakukan perusahaan.

Nilai koefisien $\beta_{2}$ sebesar $-0,284$ menunjukan jika nilai kepemilikan institusional $\left(\mathrm{X}_{2}\right)$ meningkat sebesar 1 satuan, maka CETR menurun sebesar 0,284 satuan dengan asumsi variabel independen lainnya konstan. Semakin rendah 
nilai CETR mencerminkan semakin tingginya tingkat tax avoidance dan sebaliknya, sehingga penurunan nilai CETR perusahaan perusahaan menunjukan peningkatan tindakan tax avoidance $(\mathrm{Y})$ yang dilakukan perusahaan.

Nilai koefisien $\beta_{3}$ sebesar $-0,461$ menunjukan jika nilai komisaris independen $\left(X_{3}\right)$ meningkat sebesar 1 satuan, maka CETR menurun sebesar 0,461 satuan dengan asumsi variabel independen lainnya konstan. Semakin rendah nilai CETR mencerminkan semakin tingginya tingkat tax avoidance dan sebaliknya, sehingga penurunan nilai CETR perusahaan perusahaan menunjukan peningkatan tindakan tax avoidance $(\mathrm{Y})$ yang dilakukan perusahaan.

Nilai koefisien $\beta_{4}$ sebesar -0,207 menunjukan jika nilai komite audit $\left(\mathrm{X}_{4}\right)$ meningkat sebesar 1 satuan, maka CETR menurun sebesar 0,207 satuan dengan asumsi variabel independen lainnya konstan. Semakin rendah nilai CETR mencerminkan semakin tingginya tingkat tax avoidance dan sebaliknya, sehingga penurunan nilai CETR perusahaan perusahaan menunjukan peningkatan tindakan tax avoidance $(\mathrm{Y})$ yang dilakukan perusahaan.

Uji kelayakan model (F) bertujuan untuk mengetahui apakah semua variabel independen atau bebas yang dimasukkan dalam model mempunyai pengaruh secara bersama-sama (simultan) terhadap variabel dependen atau terikat. Model dikatakan layak apabila nilai signifikansi $\mathrm{F}$ atau Probabilities value $<\mathrm{a}=0,05$. 9 berikut.

Hasil uji kelayakan model (uji F) dalam penelitian ini disajikan pada tabel Tabel 9. Hasil Uji Kelayakan Model (Uji F)

\begin{tabular}{|c|c|c|c|c|c|c|}
\hline ANOV & & & & & & \\
\hline Model & & Sum of Squares & $\mathrm{df}$ & Mean Square & $\mathrm{F}$ & Sig. \\
\hline 1 & Regression & 21,603 & 4 & 5,401 & 7,458 & $0,000^{\mathrm{b}}$ \\
\hline & Residual & 72,413 & 100 & 0,724 & & \\
\hline & Total & 94,016 & 104 & & & \\
\hline
\end{tabular}

a. Predictors: (Constant), Komite Audit, Financial Distress, Komisaris Independen, Kepemilikan Institusional

b. DependentVariable: Tax Avoidance

Sumber: Data Penelitian, 2019

Tabel 9 menunjukan bahwa nilai $\mathrm{F}$ hitung sebesar 7,458 dengan tingkat signifikansi sebesar 0,000. Nilai tersebut lebih kecil dari $\alpha=0,05$. Hasil tersebut menunjukan bahwa variabel-variabel independen beserta interaksinya berpengaruh terhadap variabel dependennya yaitu tax avoidance.Hasil tersebut menunjukan bahwa model persamaan dalam penelitian ini layak untuk digunakan sebagai alat analisis.

Nilai koefisien determinasi $\left(R^{2}\right)$ merupakan suatu pengujian yang dilakukan untuk mengetahui kekuatan hubungan linear antara variabel dependen dengan variabel independen dan menjelaskan bagaiman arah hubungan antara variabel independen dan dependen.R-Square berada antara nol dan satu.

Hasil uji koefisien determinasi $\left(\mathrm{R}^{2}\right)$ dalam penelitian ini disajikan pada tabel 10 berikut. 
Tabel 10. Hasil Uji Koefisien Determinasi $\left(\mathbf{R}^{2}\right)$

\begin{tabular}{lllll}
\multicolumn{2}{l}{$\begin{array}{l}\text { Model Summary } \\
\text { Model }\end{array} \quad \mathrm{R}$} & $\mathrm{R}$ Square & Adjusted $R$ Square & $\begin{array}{l}\text { Std. Error of the } \\
\text { Estimate }\end{array}$ \\
\hline 1 & $0,479 \mathrm{a}$ & 0,230 & 0,199 & 0,85095840
\end{tabular}

Sumber: Data Penelitian, 2019

Tabel 10 menunjukan bahwa besarnya nilai Adjusted $R$ Square sebesar 0,199 memiliki arti bahwa sebesar 19,9 persen variasi tax avoidance dapat dijelaskan oleh variabel financial distress, kepemilikan institusional, komisaris independen, dan komite audit. Sisanya sebesar 80,1 persen dipengaruhi oleh variabel lain yang tidak dimasukkan dalam penelitian ini.

Tabel 11. Hasil Uji Hipotesis (Uji t)

\begin{tabular}{|c|c|c|c|c|c|c|}
\hline \multirow[b]{2}{*}{ Model } & & \multicolumn{2}{|c|}{$\begin{array}{l}\text { Unstandardized } \\
\text { Coefficients }\end{array}$} & \multirow{2}{*}{$\begin{array}{l}\text { Standardized } \\
\text { Coefficients } \\
\text { Beta }\end{array}$} & \multirow[b]{2}{*}{$\mathrm{t}$} & \multirow[b]{2}{*}{ Sig. } \\
\hline & & B & Std. Error & & & \\
\hline \multirow[t]{5}{*}{1} & (Constant) & $-0,163$ & 0,086 & & $-1,888$ & 0,062 \\
\hline & FD & $-0,353$ & 0,113 & $-0,390$ & $-3,115$ & 0,002 \\
\hline & INST & $-0,284$ & 0,134 & $-0,291$ & $-2,120$ & 0,036 \\
\hline & KIND & $-0,461$ & 0,123 & $-0,386$ & $-3,765$ & 0,000 \\
\hline & KoA & $-0,207$ & 0,092 & $-0,206$ & $-2,260$ & 0,026 \\
\hline
\end{tabular}

Sumber: Data Penelitian, 2019

Berdasarkan Tabel 11, dapat dijelaskan, Hipotesis pertama menyatakan bahwa financial distress berpengaruh negatif pada tax avoidance. Tabel 11 menunjukan bahwa -0,353 sebagai nilai koefisien regresi dan didapatkan nilai $P$ Value sebesar 0,002 dimana memiliki nilai yang lebih rendah dari ayang telah ditentukan yaitu 0,05. Hasil ini menunjukan bahwa Z-Scorememiliki pengaruh negatif pada CETR.Nilai koefisien regresi $\beta_{1}$ sebesar $-0,353$ menunjukan hubungan negatif antara Z-Score dengan CETR.Hasil pengujian bahwa financial distress berpengaruh negatif pada tax avoidance, sehingga hipotesis pertama diterima.

Hipotesis kedua menyatakan bahwa kepemilikan institusional berpengaruh negatif pada tax avoidance. Tabel 11 menunjukan bahwa -0,284 sebagai nilai koefisien regresi dan didapatkan nilai $P$-Value sebesar 0,036 dimana memiliki nilai yang lebih rendah dari a yang telah ditentukan yaitu 0,05. Hasil ini menunjukan bahwa kepemilikan institusional berpengaruh negatif pada CETR.Nilai koefisien regresi $\beta_{2}$ sebesar $-0,284$ menunjukan hubungan negatif antara kepemilikan institusional dengan CETR.Hasil pengujian bahwa kepemilikan institusionalberpengaruh positif pada tax avoidance, sehingga hipotesis kedua ditolak.

Hipotesis ketiga menyatakan bahwa komisaris independen berpengaruh negatif pada tax avoidance. Tabel 11 menunjukan -0,461 sebagai nilai koefisien regresi dan didapatkan nilai $P$-Value sebesar 0,000 dimana memiliki nilai yang lebih rendah dari a yang telah ditentukan yaitu 0,05. Hasil ini menunjukan bahwa komisaris independen berpengaruh negatif pada CETR. Nilai koefisien regresi $\beta_{3}$ sebesar $-0,461$ menunjukan hubungan negatif antara komisaris 
independen dengan CETR. Hasil pengujian bahwa komisaris independen berpengaruh positif pada tax avoidance, sehingga hipotesis ketiga ditolak.

Hipotesis keempat menyatakan bahwa komite audit berpengaruh negatif pada tax avoidance. Tabel 11 menunjukan bahwa -0,207sebagai nilai koefisien regresi dan didapatkan nilai $P$-Value sebesar 0,026 dimana memiliki nilai yang lebih rendah dari a yang telah ditentukan yaitu 0,05 . Hasil ini menunjukan bahwa komite audit berpengaruh negatif pada CETR. Nilai koefisien regresi $\beta_{4}$ sebesar -0,207 menunjukan hubungan negatif antara komite audit dengan CETR. Hasil pengujian bahwa komite auditberpengaruh positif pada tax avoidance, sehingga hipotesis keempat ditolak.

Berdasarkan Tabel 11, variabel corporate governance diproksikan dengan financial distress (FD) memiliki nilai koefisien regresi sebesar -0,353 dengan nilai $P$-Value sebesar 0,002 lebih kecil dari $a=0,05$. Hasil pengujian bahwa financial distress berpengaruh negatif pada tax avoidance, sehingga hipotesis pertama diterima.

Hasil ini sejalan dengan teori legitimasi yang menyatakan, perusahaan yang telah menyesuaikan sistem pengelolaan perusahaan yang berorientasi pada keberpihakan terhadap sosial dengan nilai dan norma sosial yang berlaku akan mendapat pengakuan atau legitimasi sehingga memeroleh citra positif (Lanis \& Richardson, 2013). Perusahaan yang mengalami financial distress dimana perusahaan tersebut mengalami kesulitan keuangan, maka perusahaan dipandang terlalu beresiko untuk melakukan Tax Avoidance. Sebab perusahaan yang melakukan Tax Avoidance dalam kondisi financial distressakan semakin sulit dalam kegiatan pendanaan perusahaan. Hasil penelitian ini mengkonfirmasi pernyataan Masri dan Martani (2012) yang menjelaskan bahwa ketika perusahaan yang mengalami financial distress melakukan upaya tax avoidance, maka perusahaan dapat memperbesar risiko semakin memburuknya citra perusahaan dan memberikan sinyal negatif kepada investor atas tindakan penghindaran pajak yang dilakukan sehingga dapat meningkatkan cost of debt perusahaan.

Berdasarkan Tabel 11, variabel corporate governance diproksikan dengan kepemilikan institusional (INST) memiliki nilai koefisien regresi sebesar -0,284 dengan nilai $P$-Value sebesar 0,036 lebih kecil dari $a=0,05$. Hasil pengujian bahwa kepemilikan institusionalberpengaruh positif pada tax avoidance, sehingga hipotesis kedua ditolak.

Kaitannya dengan teori keagenan yaitu adanya konflik kepentingan, institusi pendiri perusahaan akan mementingkan dirinya sendiri sesuai dengan apa yang menguntungkan mereka tanpa memperdulikan kepentingan perusahaan. Dengan adanya kepemilikan saham oleh institusi pendiri perusahan dalam perusahaan, membuat manajer lebih agresif untuk melakukan penghindaraan pajak. Institusi pendiri perusahaan sengaja menghindari pajak dengan cara meningkatkan beban melalui penggunaan metode dan kebijakan akuntansi tertentu sehingga laba menjadi lebih kecil yang menyebabkan tindakan Tax Avoidance dilakukan.

Berdasarkan Tabel 11, variabel corporate governance diproksikan dengan komisaris independen (KIND) memiliki nilai koefisien regresi sebesar -0,461 dengan nilai $P$-Value sebesar 0,000 lebih kecil dari $a=0,05$. Hasil pengujian 
bahwa komisaris independenberpengaruh positif pada tax avoidance, sehingga hipotesis ketiga ditolak.

Berdasarkan hasil penelitian, semakin tinggi jumlah komisaris independen maka semakin besar tanggung jawab untuk memenuhi kewajiban pajak, dimana hal tersebut tidak menutup kemungkinan perusahaan akan merasa tertekan atas tanggung jawabnya, maka kemungkinan untuk melakukan tax avoidance semakin besar untuk dilakukan. Kaitannya dengan teori agensi yaitu munculnya masalah keagenan yang berupa konflik kepentingan (conflict of interest), dimana keinginan dari agen yang berbeda dengan apa yang diinginkan oleh prinsipal akan memunculkan konflik kepentingan diantara keduanya. Hasil ini tidak sejalan dengan hasil penelitian yang dilakukan oleh Prakosa (2014) menunjukan bahwa proporsi dewan komisaris independen berpengaruh negatif terhadap tax avoidance.

Berdasarkan Tabel 11, variabel corporate governance diproksikan dengan komite audit (KoA) memiliki nilai koefisien regresi sebesar -0,207 dengan nilai $P$ Value sebesar 0,026 lebih kecil dari $a=0,05$. Hasil pengujian bahwa komite audit berpengaruh positif pada tax avoidance, sehingga hipotesis keempat ditolak.

Kaitannya dengan teori agensi yaitu munculnya masalah keagenan yang berupa asimetris informasi. Agen bisa saja memberikan informasi yang tidak benar kepada prinsipal, seolah-olah perusahaan sedang berkinerja baik walaupun kenyataan tidak demikian. Ketidaktahuan prinsipal memberikan celah untuk melakukan manipulasi laporan keuangan bagi kepentingan dirinya sendiri.

\section{SIMPULAN}

Hasil dari penelitian adalah financial distress berpengaruh negatif pada praktik tax avoidance, yang artinya semakin tinggi financial distress yang dialami perusahaan akan menurunkan niat manajemen untuk melakukan tax avoidance. Kepemilikan institusional memiliki pengaruh yang positif pada praktik tax avoidance. Pengaruh positif ini memiliki arti ketika proporsi kepemilikan institusional meningkat, maka praktik tax avoidance akan meningkat. Ukuran dewan komisaris independen berpengaruh positif pada praktik tax avoidance, yang artinya semakin tinggi proporsi komisaris independen, maka praktik tax avoidanceakan meningkat. Komite audit memiliki pengaruh yang positif pada praktik tax avoidance. Pengaruh positif disini memiliki arti ketika komite audit perusahaan mengalami peningkatan, maka tax avoidance akan meningkat.

Berdasarkan hasil dan simpulan penelitian, maka saran yang dapat diberikan yaitu, bagi penelitian selanjutnya diharapkan dapat melakukan penelitian kembali di perusahaan sektor lainnya yang terdaftar di BEI dengan periode pengamatan yang berbeda. Nilai adjusted $R$ Square yang rendah yaitu sebesar 19,9 persen menunjukan bahwa adanya keterbatasan variabel independen yang digunakan dalam menjelaskan variabel denpenden (tax avoidance). Bagi peneliti selanjutnya diharapkan dapat meneliti variabel lain yang dapat mendeteksi adanya tindakan tax avoidance seperti kepemilikan manajerial, profitabilitas, CSR, dan capital intensity ratio. 


\section{REFERENSI}

Altman, E. I., \& Hotchkiss, E. (2011). Corporate Financial Distress and Bankruptcy: Predict and Avoid Bankruptcy, Analyze and Invest in Distressed Debt, Third Edition. Corporate Financial Distress and Bankruptcy: Predict and Avoid Bankruptcy, Analyze and Invest in Distressed Debt, Third Edition.

Annisa, N. A., \& Kurniasih, L. (2012). Pengaruh Corporate Governance Terhadap Tax Avoidance. Jurnal Akuntansi \& Auditing, 8(2), 95-189.

Arianandini, P. W., \& Ramantha, I. W. (2018). Pengaruh Profitabilitas, Leverage, dan Kepemilikan Institusional pada Tax Avoidance. E-Jurnal Akuntansi Universitas Udayana, 22(3), 2088-2116.

Brondolo, J. (2015). Collecting Taxes During an Economic Crisis: Challenges and Policy Options. IMF Staff Position Notes, 2009(17), 2.

Carlson, S. J., \& Bathala, C. T. (1997). Ownership differences and firms' income smoothing behavior. Journal of Business Finance and Accounting, 24(2), 179196.

Chen, S., Chen, X., Cheng, Q., \& Shevlin, T. (2010). Are family firms more tax aggressive than non-family firms? Journal of Financial Economics, 95(1), 41-61.

Dewi, G. A. P., \& Sari, M. M. R. (2015). Pengaruh Insentif Eksekutif , Corporate Risk dan Corporate Governance pada Tax Avoidance. E-Jurnal Akuntansi Udayana, 13(1), 50-67.

Fadhilah, R. (2014). Pengaruh Good Corporate Governance Terhadap Tax Avoidance ( Studi Empiris Pada Perusahaan Manufaktur yang Terdaftar di BEI 2009-2011). Fakultas Ekonomi Universitas Negeri Padang.

Gray, R., Owen, D., \& Adams, C. (1996). Accounting \& accountability: changes and challenges in corporate social and environmental reporting. Prentice Hall.

Gupta, S., \& Newberry, K. (1997). Determinants of the Variability in Corporate Effective Tax Rates: Evidence from Longitudinal Data. Journal of Accounting and Public Policy, 16(1), 1-34.

Hanlon, M., \& Heitzman, S. (2010). A Review of Tax Research. Journal of Accounting and Economics, 50(2), 127-178.

Jensen, M. C., \& Meckling, W. H. (1976). Theory Of The Firm: Managerial Behavior, Agency Costs and Ownership Structure. Journal of Financial Economics, 3(4), 305-360.

Khurana, I. K., \& Moser, W. J. (2009). Institutional Ownership and Tax Aggressiveness, 1-42.

Lanis, R., \& Richardson, G. (2013). Corporate social responsibility and tax aggressiveness: A test of legitimacy theory. Accounting, Auditing and Accountability Journal, 26(1), 75-100.

Maharani, I. G. A. C., \& Suardana, K. A. (2014). Pengaruh Corporate Governance, Profitabilitas, dan Karakteristik Eksekutif Pada Tax Avoidance Perusahaan Manufaktur. E-Jurnal Akuntansi Universitas Udayana, 9(2), 525-539.

Maraya, A. D., \& Yendrawati, R. (2016). Pengaruh Corporate Governance dan Corporate Social Responsibility terhadap Tax Avoidance. Jurnal Akuntansi \& Auditing Indonesia, 20(2), 147-159.

Masri, I., \& Martani, D. (2012). Pengaruh Tax Avoidance Terhadap Cost of Debt. Program Pasca Sarjana Ilmu Akuntansi Departemen Akuntansi Fakultas Ekonomi 
Universitas Indonesia, 1, 1-28.

Meilia, P., \& Adnan. (2017). Pengaruh Financial Distress, Karakteristik Eksekutif, dan Kompensasi Eksekutif terhadap Tax Avoidance pada Perusahaan Jakarta Islamic Index. Jurnal Ilmiah Mahasiswa Ekonomi Akuntansi, 2(4), 84-92.

Minnick, K., \& Noga, T. (2010). Do corporate governance characteristics influence tax management? Journal of Corporate Finance, 16(5), 703-718.

Prakosa, K. B. (2014). Pengaruh Profitabilitas, Kepemilikan Keluarga dan Corporate Governance Terhadap Penghindaran Pajak Di Indonesia. SNA 17 Mataram, Lombok Universitas Mataram 24-27 Sept 2014, 1-27.

Radifan, R. (2015). Analisis Pengaruh Mekanisme Good Corporate Governance Terhadap Kemungkinan Financial Distress, 1-71.

Rani, P. (2017). Pengaruh Ukuran Perusahaan, Financial Distress, Komite Audit, dan Komisaris Independen Terhadap Tax Avoidance. Jurnal Akuntansi Dan Keuangan, 6(2), 221-241.

Reza, F. (2012). Pengaruh Dewan Komisaris dan Komite Audit Terhadap Penghindaran Pajak. Skripsi Ilmiah Universitas Indonesia.

Richardson, G., Taylor, G., \& Lanis, R. (2015). The impact of financial distress on corporate tax avoidance spanning the global financial crisis: Evidence from Australia. Economic Modelling, 44, 44-53.

Santoso, T. B. (2014). Pengaruh Corporate Governance Terhadap Penghindaran Pajak Perusahaan. Diponegoro Journal Of Accounting, 3(Semarang: Universitas Diponegoro), 1-37.

Shleifer, A., \& Vishny, R. W. (1997). A Survey Of Corporate Governance. The Journal of Finance, 52(1), 35-55.

Suchman, M. C. (1995). Managing legitimacy: Strategic and institutional approaches. Academy of Management Review, 20(3), 571-610.

Timothy, Y. C. K. (2010). Effects Of Corporate Governance On Tax Aggressiveness. Hong Kong Baptist University, 18(6), 2691-2697. 